\title{
THE RELATION OF THE CHORDA DORSALIS TO THE FNTODERMAL COMPONENT OF THE HYPOPHYSIS
}

\author{
WAYNE J. ATWELL
}

From the Department of Anatomy, University of Michigan

TWELVE FIGURES

The mode of termination of the anterior end of the notochord has been variously interpreted by authors. The older writers thought the chorda to present a causal relation to the head flexure of the embryo; to act mechanically in drawing out the infundibulum of the pituitary from the brain wall; or to form, after a similar manner, the entodermal diverticulum known as Seessel's pouch. Later writers, while not necessarily arguing for a causal relationship, have noted the existence of contacts between notochord and hypophysis and between notochord and fore-gut. Recently the rôle of the entoderm in the formation of the hypophysis has occupied the attention of a number of observers. It is the object of this communication to call attention to an observed relation of the chorda to the entodermal component of the hypophysis and to attempt the explanation of certain connections of chorda and hypophysis.

An exhaustive review of the literature covering the development of the hypophysis will not be here attempted. For a very complete bibliography on this subject the interested reader may be referred to Stendell's monograph in Oppel's Lehrbuch and to the recent contributions of Bruni and Woerdeman (1914). Neither will the much-perturbed question of the origin of the notochord receive attention. For a theoretical study of this question a recent article by Triepel may be consulted. Only the literature which seems especially pertinent will be referred to.

The Entodermal Component of the Hypophysis. Rathke, whose name is used in designating the epithelial pouch from which the main body of the hypophysis arises, thought the structure to be derived from the anterior end of the fore-gut and thus to be entodermal. It was not until in 1873 that the now commonly accepted view of the ectodermal 
origin of Rathke's pocket was established. Then, in rapid succession, came the contributions of Goette, Mihalkovics and Balfour stating that the pocket is 'pinched off' from the mouth invagination just anterior to the oral plate. As Balfour points out, Rathke's early mistake (shared by His, W. Müller and others) is undoubtedly due to the fact that he examined embryos in stages after the rupture of the oral membrane- " when it would naturally be impossible to tell whether the pinching off was from the epiblast of the mouth invagination or from the hypoblast of the throat."

The most recent writer to maintain that the glandular portion of the pituitary develops entirely from entoderm is Prather, who describes Amia calva. Prather says: "Thus, I repeat, there can be detected no fold or overgrowth of ectoderm to give rise to the hypophysis, nor overgrowth of the entoderm. Its cells are differentiated in situ apparently by longitudinal division of the cells constituting the roof of the fore-gut." Prather's contentions have not been widely accepted. Previously, the hypophysis in Amia had been stated by Dean to arise from the ectoderm. In the same year that Prather's communication appeared Reighard stated emphatically that the Amian hypophysis has its origin entirely from ectoderm. Gregory for the same form, states that the origin is both ectodermal and entodermal. P. E. Smith has attacked the problem anew and comes to the conclusion that the anlage is ectodermal, but adds that "it can be said with considerable probability that the entoderm contributes to the composition of the hypophysis." For other classes of the vertebrate kingdom many observers have recorded the existence of a more or less important entodermal component of the hypophysis.

Kupffer has described a growth from the cephalic end of the foregut to meet the dorsal wall of Rathke's pocket. This condition he interpreted as an attempted recurrence of an older pre-oral mouth, or paleostoma. He considers that the entoderm makes important contribution to the epithelial lobe of the hypophysis.

St. Remy, in studying chick embryos at about the seventieth hour of incubation, saw a communication between the cavities of Seessel's and Rathke's pouches. This singular communication, which appears to be of short duration, shows itself as an extremely fine orifice piercing the inferior part of the epithelial partition between the two invaginations. Seessel's pocket produces a solid bud which acquires a fine lumen. The bud persists until about the sixth day and then atrophys completely. "So the pharyngeal pocket of birds is to be considered as the representative of the entodermal part of the hypophysis, but only as a rudimentary one which takes no anatomical part in its formation."

Nusbaum has observed (dog embryos: $9 \mathrm{~mm}, 14 \mathrm{~mm}, 15-16 \mathrm{~mm}$ ) that Seessel's pouch grows forward and meets the hypophyseal pocket. The lumen is obliterated in this part. This solid cord later becomes segmented into two or three cell groups lying close to one another, "von denen die oberste und ansehnlichste mit der hinteren und unteren 
Wand der blasenartigen Erweiterung der Hypophyse innig sich verbindet. Diese Zellgruppe geht später, wenigstens teilweise, in die Wand der wachsenden Blase selbst über, während der Rest der ungewandelten Seessel'schen Tasche allmählich spurlos verschwindet." Nusbaum agrees with Kupffer in regarding these appearances as a degenerated recurrence of a pre-oral mouth.

Valenti, leading a number of Italian observers, has described an 'ecto-entodermal fusion' in the chick, somewhat similar to that seen by St. Remy. However, Valenti does not describe a communicating orifice. In certain amphibia he notes an entodermal cord, located some distance caudal to the mouth region, with which the cephalic end of the chorda is in close relation. This entodermal cord later takes on a semilunar form and contributes to the origin of the epithelial lobe of the hypophysis.

A comparative study has recently been made by Bruni in an attempt to homologize the entodermal components of the hypophysis. According to this observer in all the amniotes the entoderm contributes to the formation of the hypophysis in three different ways:

a) By an incorporation of Seessel's pouch (remains of the anterior end of the fore-gut). This contributes in that it helps to form a 'vestibolo faringoipofisario' located at the buccal border of the hypophyseal sac. It is later reduced to form a 'peduncolo faringoipofisario.'

b) By a diverticulum which is located between Rathke's and Seessel's pockets, and which may be called the 'diverticolo medio.'

c) By a solid bud which arises from the top of Seessel's pouch'gemma della tasca di Seessel.'

Bruni's work will be again referred to in considering certain of my own findings.

Relations of Chorda to Hypophysis. W. Müller and Dursy state that the anterior end of the chorda is attached to the base of the fore-brain. It aids mechanically in drawing out the infundibular process. Other early observers held the opinion that the chorda is responsible, in a similar manner, for the drawing out of the hypophyseal sac. Mihalkovics denies both of these contentions. For the rabbit he states that the chorda, immediately after the rupture of the oral membrane, to use his own words, "zieht, die blinde Bucht des Vorderdarms umkreisend, bis an den oberen Stumpf der durchgerissen Rachenhaut und endet ganz nahe beim Hornblatte." Later the chorda constantly touches the ectoderm at the dorsal wall of the forming hypophyseal sac. In denying that the chorda is responsible for the drawing out of the hypophyseal sac Mihalkovics calls attention to the fact that if such were the case the chorda should be attached to the upper angle of the hypophysis. This is indeed true in bird embryos, he states, but in the rabbit the notochord is attached to the inferior half of the dorsal wall of the hypophysis. This attachment is soon lost by the ingrowth of connective tissue.

Aside from attachments between chorda and hypophysis, which were thought to assist mechanically in forming the organ, Reichert (1840) 
and His (1868) considered the hypophysis to be derived from the anterior end of the notochord. Dursy (1868) states that the chorda contributes the vascular stroma of the hypophysis, while the epithelial and nervous parts he considers as coming from the fore-gut and brain, respectively.

Koelliker (for a rabbit embryo of 11 days) has noted as proceeding from the inferior part of the dorsal wall of the hypophysis a structure which he describes in these words: "ein dicker zapfenförmiger nach hinten gerichteten Vorsprung von $76 \mu$ Dicke (Länge), der auf das vorderste Chorda ende zugeht und wie mit demselben zuzammenzuhangen scheint, bei genaurer Untersuchung jedoch durch eine Spalte von etwa $2 \mu$ von demselben getrennt ist." This 'chordazapfen' of the hypophyseal wall is composed of the same kind of cells as the dorsal wall and shows no demarcation from it. Koelliker takes this union as indicating an ectodermal origin for the notochord.

Woerdeman, observing embryos of Sus scrofa corresponding in age to Nos. 71 and 78 in Keibel's Normentafel, has seen a true contact between the chorda and the dorsal wall of Rathke's pocket. He believes that he is justified in calling it a true contact because at the place of union there is no membrana propia intervening between the two structures; at this place thers is a very noticeable thickening of the dorsal wall of Rathke's pocket; and the arrangement of the nuclei is very irregular. Woerdeman has noted, in connection with these observations, that Seessel's pouch has lost its lumen in the upper part and that it is directed toward the insertion of the chorda into the hypophyseal wall. He notes a similarity to Nusbaum's observations wherein a strand of cells from Seessel's pouch was seen to become attached to the dorsal wall of the hypophysis. In comparing this with his own findings Woerdeman's words read:

Ist dies nun auch bei Sus scrofa der Fall, was meines Erachtens nicht unmöglich sein wird, aber welches zu constatieren ich nicht das Glück gehabt habe, dann kann es wichtig sein, die Stelle zu kennen wo die Verbindung stattfindet, da mir die Möglichkeit nicht ausgeschlossen zu sein scheint, das die Rathkesche Tasche, die Chorda dorsalis und das Seesselsche Säckchen in eine sehr innige Beziehung zu einander kämen.

Relation of Chorda to Entoderm. That the notochord is attached to the entoderm in the mid-line at an early stage seems commonly acknowledged. Keibel firmly maintains that this union is secondary in the guinea-pig and also in the rabbit. This contact between chorda and entoderm persists until a short time after the rupture of the oral plate. The last point of contact is not at the stump of the oral plate but somewhat more caudal. With the final cutting off, to quote Keibel, "entstehen Bilder, welche Selenka zu der aufstellung seiner Gaumentasche geführt haben." Keibel denies that the formation of the chorda has any connection with the hypophysis or oral plate, either directly or mechanically. 
For the chick, Lillie, in his text-book, speaks thus briefly on the early connection of chorda and entoderm:

The head process becomes inseparably fused with the entoderm in the middle line immediately after its formation; and this fusion is continued back along the axis of the primitive streak. The fusion is particularly intimate and persistent at the extreme anterior end of the head process; behind this point the notochord and entoderm soon separate again in the course of development. But the anterior end of the notochord remains attached to the entoderm for a considerable period after the formation of the head-fold.

Selenka has described a peculiar 'gland-like' structure in the embryonic opossum. In its complete state this 'Gaumentasche,' as he calls it, consists of a pouch with 2-4 hollow or solid out-pouchings. The pocket empties into the fore-gut; dorsally it is in direct communication with the substance on the notochord. Selenka states: "Die Gaumentasche ist mithin nichts Anderes als das vordere ausgehöhlte Ende der Chorda, eine vordere Chordatasche." This investigator has found a similar structure in the higher vertebrates and believes that it exists in all forms. He thinks that Seessel's pocket cannot be the 'Gaumentasche' for in both chick and duck embryos he has observed that the 'Gaumentasche' is already closed and its opening into the pharynx constricted by the time the hypophyseal sac has begun to form. According to him Seessel's pocket is only a mechanically modified remains of the fore-gut.

In a brief note, Bawden has described what he interprets as Selenka's 'pharyngeal sac' in the duck and finds that it is not branched as in the opossum. It is best developed in the duck embryo of five days and is transitory, leaving no trace behind it after the seventh day. In some stages the sac has been noted to become incorporated into the stalk of the hypophysis.

St. Remy (1896) after a wide study of the mode of termination of the anterior end of the chorda concludes that in all the amniotes the chorda bends itself to maintain its insertion into the epithelium, forming an angle more or less pronounced. One can distinguish an ascending part, the termination of the principal part of the chorda, and a descending part attached to the entoderm. The latter disappears constantly very early through the disintegration of its elements, which transform themselves into connective tissue. The summit of the angle and a part of the ascending branch disappear likewise.

Mrs. Gage has noted the existence in the human embryo of several points of contact between notochord and epithelium of the pharyngeal roof, caudal to Seessel's pocket. In an extended comparative study this condition was not found to be common except that it exists in a certain percentage of cases in the pig. As a summary of the comparative study Mrs. Gage states that the cephalic tip of the notochord may vary in relation, and may be in contact with the hypophysis, Seessel's pocket, or the first mesodermic head cavity She suggests 
that the last condition, which is found in the shark, may be the typical one.

Recently Huber has treated the relation of the chorda to the median pharyngeal recess or the pharyngeal bursa. His article may be consulted for a review of the work of Froriep, Killian, Levi, Meyer, Grünwald and others having a bearing on this point. Huber controverts the statement of $R$. Meyer that the pharyngeal bursa is formed from Seessel's pouch. He finds (human embryos) that the chorda is in constant relation with a diverticulum from the pharynx. The region of this contact is separated from Seessel's pocket by almost the entire future roof of the pharyngeal cavity.

\section{MATERIALS AND METHODS}

The material for this study consists of about forty rabbit embryos obtained during the first twenty days of development, and of sixteen chick embryos ranging in age from 36 to 120 hours of incubation.

The rabbit embryos, which are from the embryological collection of the Department of Anatomy, University of Michigan, were fixed in Zenker's, Carnoy's or Bouin's fluid and cut in the three dimensions. Of these series ten were especially prepared for a closely allied study and were cut into sagittal series of $5 \mu$ thickness-the younger ones on the rotary microtome, and the older ones on the sliding microtome by Huber's water-on-theknife method. The staining was done for the most part with iron-alum hematoxylin and Congo red.

The chick embryos are partly from the author's collection and partly from the embryological collection of the Department of Anatomy, University of Michigan. They were fixed in Zenker's or Carnoy's fluid and were cut into sagittal series at $5 \mu$ and $7 \mu$. Some are stained with iron-alum hematoxylin and Congo red and others with hemalum and Congo red.

In a study of the development of the hypophysis in the rabbit a number of models were prepared after the Born wax-plate method, to show the hypophysis region,. including Seessel's pouch and the anterior end of the notochord. These were made at a relatively high magnification- $-400 \times$ for the younger stages and $200 \times$ for the older ones. The models clearly show the relations existing between the anterior end of the notochord, 
Seessel's pouch and Rathke's pocket. Similar models have been made of certain of the younger chick embryos at a magnification of $300 \times$.

For the purposes of this study mid-sagittal outline drawings were reconstructed by superimposing the drawings from several consecutive sections. This corrects for any slight obliquity of cutting and presents in a single picture what could be seen as such only in a thick, exactly central section. In every instance the relations shown by the reconstructed outline drawings are substantiated by the wax-plate reconstructions.

\section{RELATIONS OF THE CHORDA IN THE RABBIT}

The earliest stages of rabbit embryos at my disposal show the notochord attached to the entoderm of the fore-gut, for a considerable distance caudal from its cephalic extremity. Figure 1 shows a mid-saggital drawing of a $3 \mathrm{~mm}$ rabbit embryo. The oral membrane is still intact and Rathke's pocket exists only as a shallow invagination. The notochord is separated from the entoderm of the fore-gut forward to a region indicated by the $\mathrm{X}$. From this point to the oral plate is a comparatively long region of contact still existing between notochord and entoderm, although in a number of places dissolution of this contact has begun. The anterior end of the notochord is rounded and is in close relation to the dorsal wall of the hypophysis invagination, but no actual point of fusion can be demonstrated. A small diverticulum extends cephalo-ventrally from the cavity of the fore-gut close to the oral plate but this may be, in part at least, an artefact due to an inbuckling of the oral plate during fixation.

A somewhat older embryo, with the oral membrane in the process of rupture, shows the notochord losing its contact with the entoderm at several places around the anterior end of the fore-gut.

A still older embryo $(5.5 \mathrm{~mm})$ shows notochord and entoderm entirely separated except for one point just ventral to the tip of the fore-gut. A mid-sagittal drawing of this embryo is shown in figure 2. Rathke's pocket has deepened considerably and its previously regular contour is being modified by the pushing in 
of the infundibular process. Immediately caudal to Rathke's pocket is Seessel's pouch or pocket, derived from the blind anterior end of the fore-gut. It is about one-half as deep as Rathke's pocket and has a somewhat wider opening into the cavity of the fore-gut. The boundary between the two pockets is well marked

Fig. 1 Reconstructed outline drawing, in mid-plane sagittal section, of head region of rabbit embryo, Series $A, 3 \mathrm{~mm}$ crown-breech length. $\times 30$. Notochord black, brain wall shaded. $R$, anlage of Rathke's pocket; $S$, Seessel's pouch (anterior end of fore-gut); $O M$, oral membrane. Notochord shown in contact with entoderm from point marked $X$ forward to dorsal attachment of oral membrane.

Fig. 2 Reconstructed outline drawing, in mid-plane sagittal section, of hypophysis region of rabbit embryo, Series D, $5.5 \mathrm{~mm}$ crown-breech length. $\times 30$. Notochord black, brain wall shaded. $R$, Rathke's pocket; $S$, Seessel's pouch. Cephalic end of notochord directed toward a bud of entoderm from near apex of Seessel's pouch.

Fig. 3 Reconstructed outline drawing, in mid-plane sagittal section, of rabbit embryo $7 \mathrm{~A}, 15$ days of development. $\times 30$. Notochord black, brain wall shaded. $H$, hypophysis; $S$, remains of Seessel's pouch. Cephalic end of notochord in proximity to bud of epithelium from Seessel's pouch.

Fig. 4 Reconstructed outline drawing, in mid-plane sagittal section, of hypophysis region of rabbit embryo $8 \mathrm{~A}, 16$ days of development. $\times 30$. Notochord black, brain wall shaded; cartilage mass of skull base stippled. $H$, hypophysis; S, remains of Seessel's pouch. A bud from Seessel's pouch is directed toward the cephalic part of the notochord.

Fig. 5 Reconstructed outline drawing, in mid-plane sagittal section, of hypophysis region of rabbit embryo, Series F, $6 \mathrm{~mm}$ crown-breech length. $\times 30$, Notochord black, brain wall shaded. $R$, Rathke's pocket, $S$, Seessel's pouch. Cephalic end of notochord in relation to buds from both Rathke's and Seessel's pouches.

Fig. 6 Reconstructed outline drawing, in mid-plane sagittal section, of head region, chick embryo of 19 somites. $\times 30$. Notochord black, brain wall shaded. $F G$, fore-gut (later Scessel's pouch); $R$, anlage of Rathke's pocket; $O M$, oral membrane. Cephalic end of notochord attached to anterior end of fore-gut; evidences of recently severed connections more caudal. Portions of entoderm in contact, or recently in contact, with notochord stippled.

Fig. 7 Reconstructed outline drawing, in mid-plane sagittal section, of head region, chick embryo of 22 somites. $\times 30$. Notochord black, brain wall shaded. $F G$, fore-gut (later Seessel's pouch); $R$, Rathke's pocket; $O M$, oral membrane. Cephalic end of notochord still attached to anterior end of fore-gut by epithelial bud (stippled).

Fig. 8 Reconstructed outline drawing, in mid-plane sagittal section, of head region, ehick embryo of 29 somites. $\times 30$. Notochord black, brain wall shaded. $S$, Seessel's pouch; $R$, Rathke's pocket. Oral membrane in process of rupture. Cephalic end of notochord attached to epithelial bud (stippled) from Seessel's pouch; bud now fused with dorsal wall of Rathke's pocket near apex. 

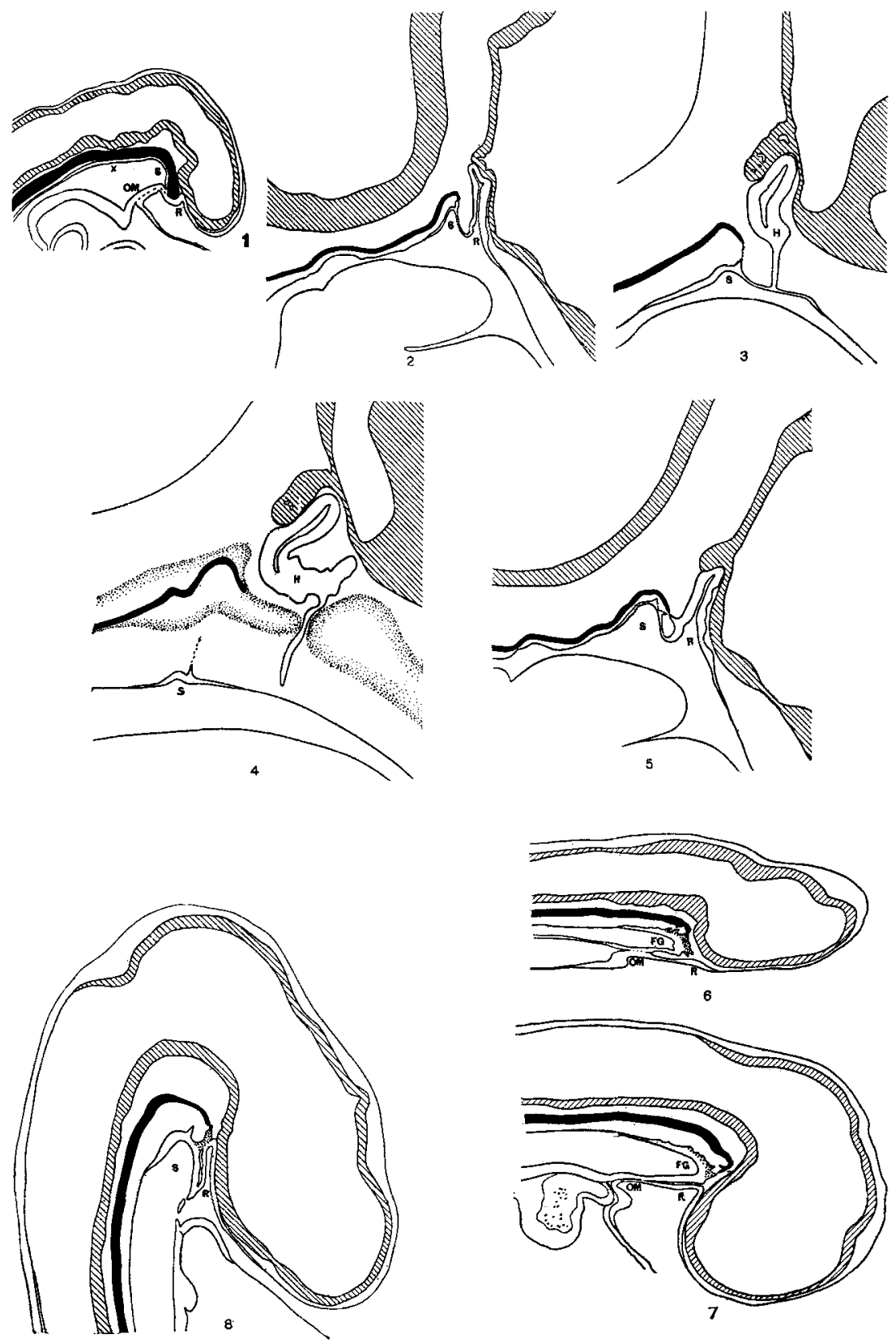
and there is no reason to doubt that the oral membrane had its upper attachment fairly between the two as they now exist. On the ventral side of the angle of Seessel's pouch appears a solid epithelial bud. The notochord follows the configuration of the entoderm as far forward as Seessel's pocket, where it dips down and comes into close relation with the solid bud of epithelium just described. An actual contact does not appear to exist, the two structures being separated by a space of $5 \mu$.

Numerous other embryos, closely staged, show the notochord in a similar close relation to a solid bud of epithelium, always in the same relative position. Gradually Seessel's pouch is reduced until it is represented only by a slight indentation of the roof of the bucco-pharynx. The reduction of the size of the epithelial bud is not always proportionate, so that it is often relatively prominent. A drawing of a 15-day rabbit embryo is presented in figure 3 . The hypophysis shows connection with the epithelium by a solid cord of cells. Seessel's pouch is found in the same relative position as in preceding embryos but is now much flattened. A well-marked epithelial bud extends from the ventral side of the pouch near its apex. This bud, arising from the epithelium by a broad base, tapers rapidly so that its apex is drawn out into a fine point. This point is directed toward the cephalic termination of the notochord, which makes a marked ventral bend and comes in proximity to the end of the epithelial bud. Between the two is a line of cells more densely arranged than the surrounding mesenchyme. The end of the notochord shows signs of degeneration: the boundary of its extremity is not well marked, large spaces occur in it, and the cytoplasm of most of the cells stains heavily with Congo red. The appearance presented warrants the interpretation that this is the last region of contact between notochord and entoderm.

By degeneration of the end of the chorda and of the epithelial bud, and by a rapid increase of connective tissues to form the skull base, the notochord becomes farther removed from any connection with the entoderm. A rabbit embryo of 16 days is shown in figure 4 . The chondrocranium is well indicated at this stage and the solid stalk of the hypophysis has lost its 
attachment to the epithelium of the bucco-pharynx. Seessel's pouch is represented by little more than an undulation of thickened epithelium. In the same relative position as in younger embryos, however, is found a solid bud. It terminates in a fine point. Extending for some distance from the end of the bud is a line of cells darker than the surrounding mesenchyme. The notochord, which more caudally is seen to lie in the ventral part of the basioccipital cartilage, cuts through the body of this cartilage mass, and after making two marked flexures ends close to the cavity of the future sella turcica. The end of the notochord shows signs of degeneration.

In rabbit embryo, Series $L$, which is almost exactly the same age as the embryo just described, a much more prominent epithelial bud occurs, but it is situated in the same relative position. In the case of this embryo the end of the bud is not drawn out to a sharp point but is rounded off and has a well-defined boundary. Likewise the notochord does not show degenerative processes at its end. Its termination is rounded up and ball-like, with a definite outline. Thus in some embryos there may appear for a time a retardation of the degeneration of the chorda which normally manifests itself quite early.

The process of separation of notochord and entoderm as here briefly outlined is confirmed by a careful examination of the many intermediate and corresponding stages composing the material for this study. In only two embryos (Series $\mathrm{F}$ and $6 \mathrm{~A}$, 13 days) was any indication of a connection between notochord and hypophysis noted. These two embryos are close together in stage of development and present much the same appearance. One of them (Series F) is shown in figure 5. Here it is seen that the end of the notochord encircles Seessel's pouch and is directed toward an outbudding from the inferior part of the dorsal wall of the hypophyseal pocket. Toward the tip of this bud is directed a bud from Seessel's pouch. The ends of the notochord, of the ectodermal bud and of the entodermal bud are all drawn out to fine points. No absolute connection can be demonstrated between any two of them but they are all three in close relation. This was believed by Woerdeman to be the case in the pig, 
although he admits his lack of material to demonstrate their "innige Beziehung zu einander."

From the scarcity of stages in the rabbit showing any indication of connection between notochord and hypophysis I am led to believe that a union of these two structures, when it does occur, is accidental rather than of normal occurrence. Figure 1 shows that in early stages the end of the notochord lies close to the dorsal wall of the forming hypophysealpocket. The presence of the notochord is responsible for an indentation of this dorsal wall showing that considerable pressure occurs between the two. It is not inconceivable, then, that a fusion may occur in a certain number of cases.

On the other hand the constancy of relation between the notochord and an epithelial bud from Seessel's pouch is noteworthy. This bud of epithelium appears constantly a short distance ventral to the top of Seessel's pouch. It is probably to be considered identical with Selenka's 'Gaumentasche' (solid in higher forms), and St. Remy's 'branche descendante' of the notochord.

\section{RELATIONS OF THE CHORDA IN THE CHICK}

My observations on chick embryos, beginning with a stage of 17 somites, are in accord with the generally accepted view that the notochord loses its attachment to the entoderm first caudally, then gradually forward. A mid-sagittal view of a 19 somite chick is shown in figure 6 , and a view of the wax reconstruction made of the hypophysis region of this chick is shown in figure 9 , A. The hypophysis anlage is indicated by a region of thickened epithelium. The connection between notochord and entoderm is lost except at the anterior end of the fore-gut. However, the entoderm shows evidences of this rocently-severed connection by a considerable region of thickening anteriorly and by several buds just caudal to the present connection. There is no connection between notochord and hypophysis anlage, nor between the latter and the entoderm of the fore-gut.

An older chick (22 somites, figs. 7 and 9, B) shows the hypophysis as a well marked angle with a broad opening into the oral invagination. The notochord shows an attachment to a drawn 
out portion of the entoderm at the anterior end of the fore-gut and presents evidences of other connections more caudal. The hypophyseal anlage is not connected with either notochord or entoderm.
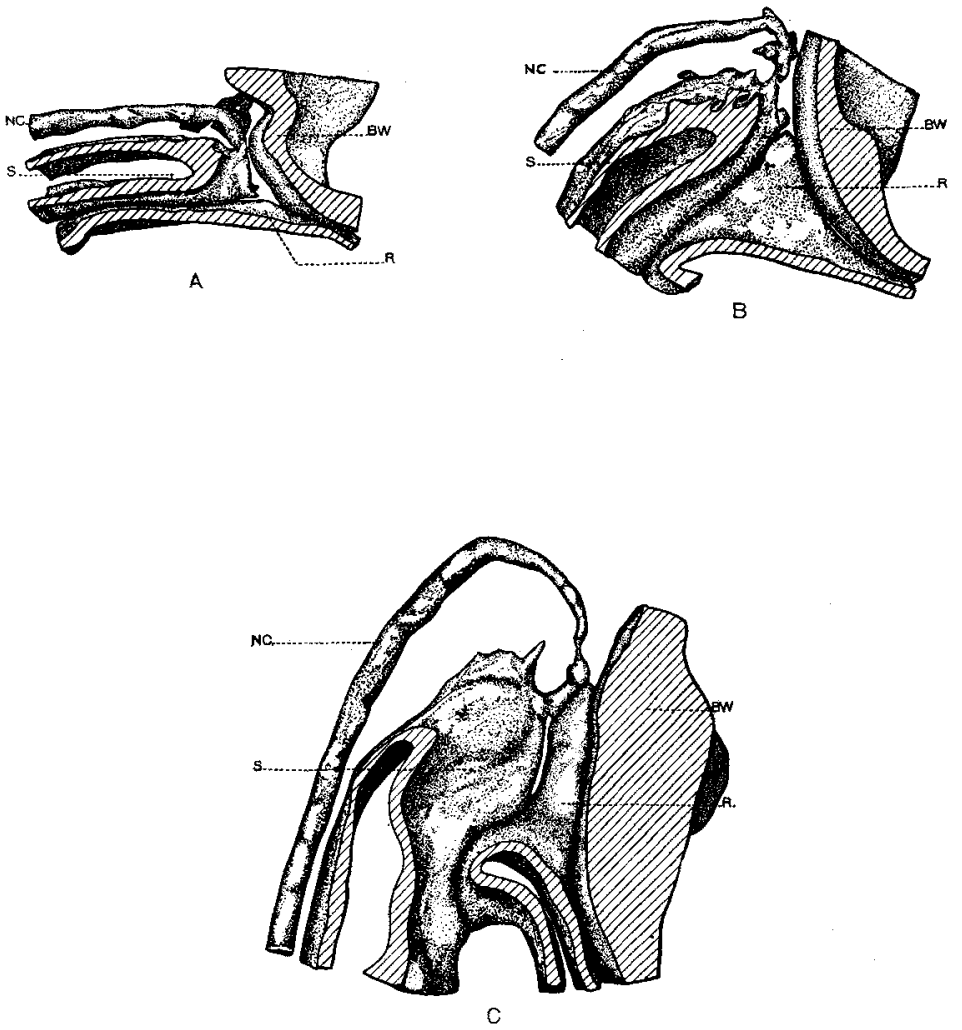

Fig. 9 Wax models of hypophysis region of chick embryos. $\times 75 . \quad A$, chick of 19 somites; $B$, chick of 22 somites; $C$, chick of 29 somites. The embryos from which these models were made are shown in mid-sagittal section in figures. 6,7 and 8 , respectively. $A$ and $B$ show cephalic end of notochord attached to bud from anterior end of fore-gut. In $C$ this bud has become fused with superior part of dorsal wall of Rathke's pocket. $N C$, notochord; $S$, Seessel's pouch (anterior end of fore-gut); $R$, Rathke's pocket; $B W$, brain wall.

An embryo with the oral membrane in process of rupture (29 somites, figs. 8 and $9, \mathrm{C}$ ) shows a marked increase in the size of the fore-brain vesicle which has resulted in a compression of the oral invagination and a flattening of the hypophyseal 
pocket. But the most noteworthy result of this compression has been the bringing together of Rathke's pocket and the epithelial bud from the entoderm which is apparently further drawn out by its persisting connection with the notochord. The bud, proceeding from the entodermal epithelium at a point slightly ventral to the cephalic end of the fore-gut, lies in connection with the ectodermal epithelium of the dorsal wall of Rathke's pocket for a considerable region near its blind end. The connection is a true fusion of entoderm and ectoderm with no demarcation between the two. The notochord makes a bend to maintain its connection with the entodermal bud. It will now be noted that the end of the notochord is nearer to the wall of Rathke's pocket than to the fore-gut (later Seessel's pouch). Here notochord, ectoderm and entoderm are in close relation. However, the notochord does not touch Rathke's pocket directly but only by means of the epithelial bud through which it maintains its connection with entoderm. At the anterior end of the fore-gut is another entodermal bud directed toward the notochord. This is to be considered as one of the remains of the earlier, more general union between notochord and entoderm. ${ }^{1}$

A strikingly similar condition is presented by another embryo of about the same age (latter half of the third day of incubation). The hypophysis region is shown in figure 10 . The oral membrane has not broken but is very thin. A bud from the entoderm lies fused with the superior part of the dorsal wall of Rathke's pocket for some distance. 'The result of this fusion is to more than double the thickness of the hypophyseal wall in this region. The notochord shows an unquestionable contact with the end of the entodermal bud by a dense line of cells, which is considered to be the anterior end of the notochord in process of disintegration.

Three other embryos, with the oral membrane in various stages of rupture, show distinctly this fusion of entoderm and

\footnotetext{
${ }^{1}$ Such appcarances are not uncommon, some embryos presenting two or even more such structures, which may persist later than the rupture of the oral membrane.
} 
ectoderm with the remains of the anterior end of the notochord in relation to the place of fusion. These five chicks cover quite well the latter part of the third day of incubation, yet in
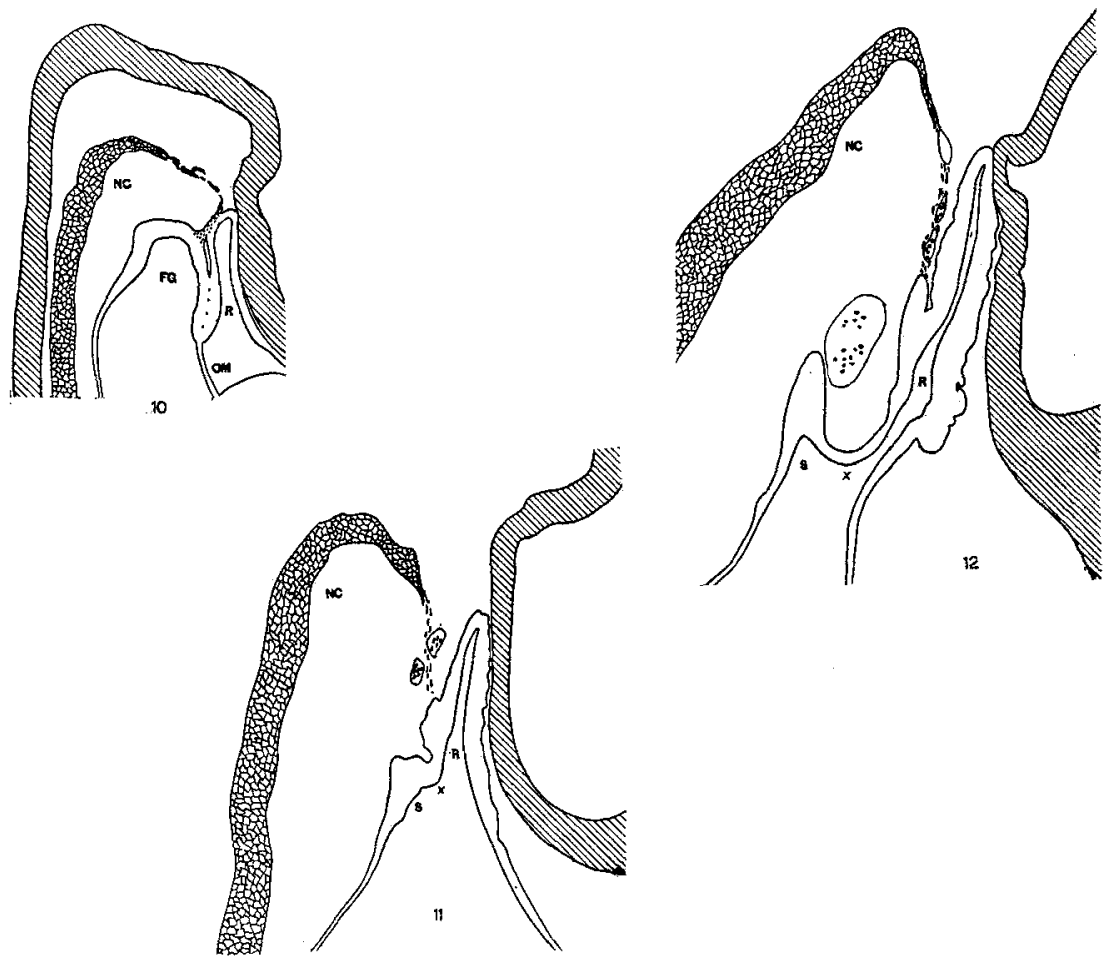

Fig. 10 Reconstructed outline drawing, in mid-plane sagittal section, of hypophysis region of chick embryo in latter half of third day of incubation. $\times 55$. Brain floor shaded. $N C$, notochord; $F G$, fore-gut (later Seessel's pouch); $R$, Rathke's pocket; $O M$, oral membrane. Shows same relations as figure 8 .

Fig. 11 Reconstructed outline drawing, in mid-plane sagittal section, of hypophysis region, chick embryo, 96 hours of incubation. $\times 55$. Brain wall shaded. $N C$, notochord; $S$, remains of Seessel's pouch; $R$, Rathke's pocket; $\mathrm{X}$, transition from ectoderm to entoderm. Fusion between Seessel's and Rathke's pockets now lost. A line of cells connects cephalic end of notochord to a bud from dorsal wall of Rathke's pocket.

Fig. 12 Reconstructed outline drawing, in mid-plane sagittal section, of hypophysis region, chick embryo, 120 hours of incubation. $\times 55$. Brain wall shaded. $N C$, notochord; $S$, remains of Seessel's pouch; $R$, Rathke's pocket; $\mathrm{X}$, transition from ectoderm to entoderm. Large blood vessel shown between Seessel's and Rathke's pockets. Notochord shows traces of an attachment to a bud from dorsal wall of Rathke's pocket. 
none of them could be found the fine communication between the cavities of Rathke's and Seessel's pouches as described by St. Remy.

In older stages the fused entodermal bud loses its connection with the fore-gut but remains attached to the ectoderm of Rathke's pocket and causes a thickening of a small portion of its dorsal wall. With this thickening the notochord shows a connection which gradually becomes less definite as its cells are drawn out and separated (St. Remy maintains that they are changed into connective tissue). The hypophysis grows most rapidly at its blind end and thus the point of entodermal fusion (with the degenerated end of the notochord in relation) comes to lie relatively nearer to the mouth of the hypophyseal pocket. This has been noted by Woerdeman, who finds (pig) that in young embryos a fusion of notochord and the dorsal wall of Rathke's pocket is found near the apex of the pocket, while in an older stage the insertion of the notochord is into the middle of the dorsal wall.

A chick of 96 hours incubation (fig. 11) shows Seessel's and Rathke's pockets in communication in the mid-plane. On the dorsal wall are found two epithelial thickenings. From the more cephalic of the two a line of cells leads to the end of the notochord. This would seem to indicate that this thickening is the location of the former ento-ectodermal fusion. The thickening is bud-like and may be what Bruni calls the 'diverticolo medio.' It is worthy of note that while the outermost part of this thickening is entodermal (remains of the bud that fused with the hypophyseal wall), yet none of this entoderm need be supposed to lie next to the lumen of the hypophyseal sac. At this stage it is rather difficult, from mid-sagittal sections, to determine the boundary between Rathke's and Seessel's pouches. An examination of more lateral sections indicates that this is at the point marked $X$ (fig. 11). The epithelial thickening caudal to this point is the tip of Seessel's pocket. Bruni calls this the "gemma della tasca di Seessel."

A chick of 120 hours incubation (fig. 12) shows much the same relations but Seessel's pouch has again assumed a more definite 
demareation from Rathke's pocket. This is due to growth of mesoderm dorsal to Rathke's pocket and especially to the development of a prominent blood vessel growing between the two. This vessel has been spoken of by several authors as a connecting branch between the internal carotids, common in bird embryos. The notochord still shows indications of a connection with a bud (which sometimes shows a lumen) from the inferior part of the dorsal wall of Rathke's pocket. This must be Bruni's 'diverticolo medio.' Small blood vessels occur in this location. If the interpretation of the point $\mathrm{X}$ as the transition between ectoderm and entoderm is correct, then the hypophysis proper contains no entodermal component except the relatively few calls fused with the dorsal wall at about the time of the rupture of the oral membrane. It is hoped that the fate of Seessel's pouch may serve as the subject of a future study.

\section{COMPARISON OF RELATIONS IN RABBIT AND CHICK}

In comparing conditions found in the rabbit with those in the chick it is seen that in both the anterior end of the notochord tends to maintain a connection with the fore-gut, as St. Remy states. This connection is aided by a bud drawn out from the epithelium. In the rabbit the bud remains for some time, gradually decreasing as the epithelium of Seessel's pouch flattens out. In the chick the rapid growth of the fore-brain and the sharpness of the cervical flexure bring this bud into contact with the growing hypophyseal wall and the two become fused. Soon afterwards the bud loses its original connection with the entoderm but remains fused with the wall of Rathke's pocket. Thus a small mass of entodermal cells becomes united with hypophysis anlage. The notochord shows indications of a connection with this mass of entodermal cells which now form a bud on the dorsal wall of Rathke's pocket. By this means the attachment of the notochord is transferred from Seessel's pouch to Ratllke's pocket.

In the rabbit, on the other hand, the notocnord does not usually come into connection with Rathke's pocket. A fusion may occur in a small percentage of cases but must be considered 
accidental. When such a union occurs a bud of entodermal epithelium may be directed toward the point of union.

These observations may be offered to explain certain connections between notochord and hypophysis as seen by Koelliker (in the rabbit) and Woerdeman (in the pig). The latter has in two cases, seen a more definite fusion than can be demonstrated in the two rabbit embryos which show evidences of such connection used in this study. These observations on the rabbit and particularly on the chick, may also serve to explain certain entodermal components of the hypophysis as noted by Kupffer (amphibia and mammals), Valenti (amphibia and birds), St. Remy (chick), and Nusbaum (dog). The findings here recorded, it seems to me, do not substantiate the view, taken by most of these writers, that the entodermal contribution to the hypophysis is of fundamental importance, especially phylogenetically; nor do they aid in the belief that the hypophysis represents a paleostome.

While the fate of Seessel's pouch and the participation of its epithelium in the composition of the hypophysis may be doubtful in the chick, it cannot be stated that this structure takes part in the formation of the hypophysis of the rabbit. As may be seen from the figures $(1-5)$ Seessel's pouch is at all times sharply defined from Rathke's. This is especially well brought out in numerous wax reconstructions made from embryos closely staged before, during and after the rupture of the oral membrane.

For the rabbit it has not been possible to demonstrate a structure similar to the 'diverticolo medio' which Bruni describes for the rat.

For the rabbit:

\section{CONCLUSIONS}

1. In the rabbit the anterior end of the notochord tends to maintain its connection with the entoderm represented by a bud from Seessel's pouch.

2. The entoderm cannot be said to contribute to the formation of the hypophysis of the rabbit.

3. Usually the notochord does not come into connection with the wall of the hypophysis in the rabbit. 
For the chick:

4. In early stages of chick embryos the anterior end of the notochord is attached to a solid bud of epithelium which extends from a point slightly ventral to the cephalic end of the fore-gut.

5 . By the growth of the forebrain and the sharpness of the cervical flexure, this entodermal bud comes into contact with the growing hypophyseal sac and fuses with it. The fusion occurs at about the time the oral membrane ruptures.

6. The bud is solid; a lumen such as is described by St. Remy could not be demonstrated.

7. The fused bud soon loses its connection with the entoderm. It remains fused with the dorsal wall of Rathke's pocket, however, and contributes a small mass of cells to the hypophysis anlage.

8. The notochord still shows indications of an attachment to the fused bud. Thus the attachment of the notochord (which is gradually becoming less and less a definite attachment) in transferred from Seessel's pouch to Rathke's pocket.

9. The relation of the notochord to this small entodermal increment of the hypophysis, and the fact that no lumen is to be found, tend to disprove the view that the entodermal contribution is anything more than an accidental union of parts.

\section{LITERATURE CITED}

Balfour, F. M. 1874 A Preliminary Account of the Development of the Elasmobranch Fishes. Quar. Jour. Micros. Sc. vol. 14, N. S., p. 324.

Bawden, H. H. 1893 Selenka's 'Pharyngeal Sae' in the Duck. Jour. Comp. Neur., vol. 3, p. 45.

Breni, Angelo Cessare 1914 Sullo sviluppo del lobo ghiandolare dell' ipofisi negli Amnioti. Internat. Monatschr. f. Anat. u. Physiol., Bd. 31, Heft 4/6.

DeAn, B. 1896 On the larval development of Amia calva. Zool. Jahrb., Bd. 9. Dursy, E. 1869 Zur Entwicklungsgeschichte des Kopfes. Tübingen.

Gage, Susanna Phelps 1906 The Notochord in Human Embryos of the Third to the Twelfth Week, and Comparisons with Other Vertebrates. Science, N. S. vol. 24, p. 295.

Goette, Alexander 1873 Kurze Mittheilungen aus der Entwickelungsgeschichte der Unke. Archiv. f. Mikr. Anat., Bd. 9, p. 396.

Gregory, E. H. 1902 Beitrage zur Entwickelungsgeschichte der Knochenfische. Anat. Hefte, Bd. 20.

Hrs, W. 1868 Untersuchungen über die erste Anlage des Wirbelthierleibs. Leipzig. 
Huber, G. Carl 1912 On the Relation of the Chorda Dorsalis to the Anlage of the Pharyngeal Bursa or the Median Pharyngeal Reess. Anat. Rec., vol. 6.

KeIbex, Franz 1889 Zur Entwickelungsgeschichte der Chorda bei Säugern. Archiv. f. Anat. u. Physiol., Anat. Abt.

Konlliker, A. 1879 Embryologische Mittheilungen: 1. Ueber das vordere Ende der Chorda dorsalis bei Kaninchen embryonen. Festschr. z. Feier d. hundertjähr. Bestehens d. naturforsch. Gesellsch. in Halle.

v. KupfFer, C. 1892 Entwicklungsgeschichte des Kopfes. Ergebnisse d. Anat. u. Entw., Bd. 2.

1894 Die Deutung des Hirnanhanges. Sitz. Ber. d. Gesellch. f. Morph. u. Physiol, zu Münehen, S. 59.

LILLE, F. R. 1908 The Development of the Chick, p. 80. Henry Holt and Company.

v. Minalkovics, Victor 1874 Wirbelsaite und Hirnanhang. Archiv. f. Mikr. Anat., Bd. 11.

MÜLlæer, W. 1868 Über Entwicklung und Bau der Hypophysis und des Processus infundibuli. Jenaische Zeitschr. f. Med. u. Naturwiss., Bd.4, S. 557 .

Nusbaum, J. 1896 Einige neue Thatsachen zur Entwickelungsgeschichte der Hypophysis cerebri bei Säugetieren., Anat. Anz., Bd. 12.

Prather, J. M. 1900 The Early Stages in the Development of the Hypophysis of Amia Calva. Biol. Bull., vol. 1, no. 2.

RAtHKe, H. 1838 Ưber die Entwicklung der Glandula pituitaria. Müller's Arch. f. Anat. Phys. u. wiss. Med.

Reichert, K. B. 1840 Das Entwickelungsleben im Wirbelthierreich. Berlin.

Rfighard, J. 1900 The Dovelopment of the Adhesive Organ and Hypophysis in Amia. Science, N. S. vol. 11, p. 251.

Selenka, Emil 1887 Die Gaumentasche der Wirbeltiere. Biol. Centralhlatt, Bd. 7.

Sмiтн, P. E. 1914 The Development of the Hypophysis of Amia Calva. Anat. Rec., vol. 8.

Stendelt, Walter 1914 Die Hypophysis Cerebri, vol. 8 in Oppel's Lehrbuch der vergleichenden Mikroscopischen Anatomie der Wirbeltiere. Fischer, Jena.

St. Remy, G. 1895 Sur la signification morphologique de la poche pharyngienne de Seessel. C. R. de la Societé de Biologie.

1896 Recherches sur l'extrémitié antérieure de la corde dorsale chez les Amniotes. Archives de Biologie, An. 14.

Triepel, Hermann 1914 Chorda Dorsalis und Keimblätter. Anat. Hefte, Bd. 50, Heft 3.

Valentr, G. 1895 Sullo svillupo dell' ipofisi. Anat. Anz., Bd. 10.

1897 Sopra i primitivi rapporti delle estremita cephaliche della corda dorsale e dell' intestino. Att. Soc. tosc. Sc. nat. Pisa.

Worrdeman, Martin W. 1913 Über einer Zuzammenhang der Chorda dorsalis mit der Hypophysenanlage. Anat. Anz., Bd. 43.

1914 Vergleichenden Ontogenie der Hypophysis. Arch. f. Mikr. Anat., Bd. 86. 